\title{
Sulama Suyu Kalitesinin Çileğin (Fragaria $x$ ananassa Duch. Rubygem) Besin Maddesi İçerikleri ve Bazı Meyve Kalite Özellikleri Üzerine Etkileri
}

\section{Șebnem Nalan AKAROĞLU*'(D), Saime SEFEROĞLU²}

\author{
${ }^{\prime}$ Adnan Menderes Üniversitesi Sultanhisar Meslek Yüksekokulu Bitkisel ve Hayvansal Üretim Bölümü, Aydın. \\ ${ }^{2}$ Adnan Menderes Üniversitesi, Ziraat Fakültesi, Toprak Bilimi ve Bitki Besleme Bölümü, Aydın.
}

Öz: Tarımsal üretimde kullanılan suların tuzluluk, ağır metaller, $\mathrm{pH}$, vb. kalitesini olușturan etmenler bakımından sorunlu olması bitkilerde fizyolojik sorunların, verim ve kalite kayıplarının ortaya çıkmasına neden olmaktadır. Bu çalıșma, sulamada kullanılan suyun kalitesinin Fragaria $x$ ananassa Duch. Rubygem çeșidine ait bitkilerde besin maddesi içeriği ve meyve kalitesi üzerine etkisini incelemek amacıyla yürütülmüștür. Çalıșmada Rubygem çilek çeșidinin frigo fideleri kullanılmıștır. Bitkiler, I/3 bahçe toprağı: I/3 yanmıș hayvan gübresi: I/3 dere kumundan olușan yetiștirme ortamı içeren plastik kasalar içerisinde yetiștirilmiștir. Araștırmada sulama suyu olarak, Aydın İli Sultanhisar İlçesi'nde çilek alanlarının büyük bir bölümünün sulanmasında rol oynayan Nazilli Sağ Sahil Sulama Birliği kanalından farklı zamanlarda alınan sular kullanılmıștır. Alınan sularda $\mathrm{pH}, \mathrm{EC}$, buharlaștırma kalıntısı, erimiș madde miktarı, geçici sertlik, toplam sertlik, $\mathrm{SAR}, \mathrm{K}^{+}, \mathrm{Ca}^{+}, \mathrm{Na}^{+}, \mathrm{Cl}^{-}, \mathrm{CO}_{3}^{-2}$, $\mathrm{HCO}_{3}$-ve $\mathrm{B}$ analizleri yapılmıștır. Suların alındığı döneme göre değișmekle birlikte en düșük pH 7.45, en yüksek 8.03 olarak saptanmıștır. $\mathrm{HCO}_{3}$ - içeriği sakıncalı düzeyde olduğu görülmüștür. Sulamada kullanılan suyun kalitesi zamana bağlı olarak

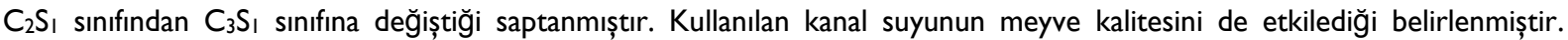
Kanal suyu ile sulanan bitkilerde bor içeriği kontrol grubu bitkilerine göre daha yüksek bulunmuștur.

Anahtar Kelimeler: çilek, su kalitesi, bitki besin maddesi içeriği, meyve kalitesi.

The Effects of Irrigation Water Quality on Nutrients Concentrations and Some Fruit Quality Properties of Strawberry (Fragaria $x$ ananassa Duch. Rubygem)

\begin{abstract}
The problematic factors such as salinity, heary metals, $\mathrm{pH}$, etc effecting quality factors of waters used in agricultural production cause physiological problems, yield losses and quality to occur in plants. This study was carried out in order to examine the quality of the water used in the irrigation on the nutrient content and fruit quality of the plants that belong to Rubygem strawberry variety. In the study, frigo seedlings of Rubygem strawberry variety plants were used. The plants were grown in plastics boxes containing //3 soil: I/3 organic manure: I/3 sand. As the irrigation water in the study, water samples taken from the Nazilli Sağ Sahil Irrigation Association in different times that played a role in watering a large part of the strawberry fields in Sultanhisar District of Aydin were used. In water samples taken, the analyzes of $\mathrm{pH}, E C$, temporary hardness, total hardness, $S A R$, $\mathrm{K}^{+}, \mathrm{Ca}^{+}, \mathrm{Na}^{+}, \mathrm{Cl}_{1} \mathrm{CO}_{3}^{-2}, \mathrm{HCO}_{3}{ }^{-}$and $\mathrm{B}$ were performed. The lowest $\mathrm{pH}$ value was found to be 7.45 and the highest $\mathrm{pH}$ value was 8.03 in water samples, though varied according to time it was taken. The content of $\mathrm{HCO}_{3}$ was determined to be damaging. It was detected that the quality of the

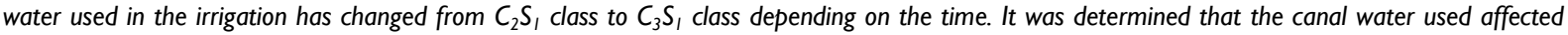
fruit quality. It was found that the boron content of the plants irrigated with canal water was higher than that of control plants.
\end{abstract}

Keywords: strawberry, water quality, plant nutrient content, fruit quality

Keywords: strawberry, water quality, plant nutrient content, fruit quality.

\section{Giriș}

Oldukça geniș bir coğrafyada doğal olarak yetișen çilek, yetiștiği coğrafyanın çeșitliği kadar tür zenginliğine sahiptir. Ticari çilek yetiștiriciliği geniș iklim sınırları içinde yapılmaktadır (Yılmaz, 2009). Bu sayede ülkemizde de hemen hemen her bölgede çilek üretimi yapılabilmektedir. Çilek bitkisi tuzlu koșullar için en hassas bitki türlerinin arasında yer almaktadır (Kurunç ve Çekiç, 2005). Tarım alanlarındaki tuzluluğun artıșını etkileyen faktörlerin bașında sulamada kullanılan suyun kalitesi gelmektedir. Sulama suyu kalitesi bașlı bașına toprak tuzluluğunu etkileyebilmektedir (Ekmekçi ve ark., 2005). Suyun bitkisel üretim için kısıtlayıcı bir faktör olduğu bölgelerde sulama suyu miktarı ve kalitesinin ortaya çıkardığı en önemli sorun günümüzde tuzluluk, alkalilik ve bor toksitesidir. Suyun tuzlulukla birlikte $\mathrm{pH}$ alkalilik ve ağır metallerden özellikle borun su kalitesini belirleyen özellikler bakımından sorunlu olması, bitkilerde fizyolojik sorunların, verim ve kalite kayıplarının ortaya çıkmasına neden olmaktadır. Sulama suyuna farklı dozlarda ilave edilen Sodyum klorür $(\mathrm{NaCl})$, sodyum bikarbonat $\left(\mathrm{NaHCO}_{3}\right)$, kalsiyum klorür $\left(\mathrm{CaCl}_{2}\right)$ ve magnezyum sülfat $\left(\mathrm{MgSO}_{4}\right)$ gibi tuzlar ile elde edilen tuzluluğa karșı bitkilerin yașadığı tuz stresi ve bu strese bağlı verim ve kalite değișimleri meydana gelmektedir. Buna göre; patlıcan bitkisinde Yașar (2003), pirinç bitkisinde Zeng ve ark. (2003); soğan bitkisinde Kadayıfçı ve ark. (2004); domates bitkisinde Sekmen ve ark. (2005); biber bitkisinde Aktaș ve ark. (2006); bezelye bitkisinde Dașgan ve ark. (2009); brokoli bitkisinde Grieve ve ark. (2010); kartopu bitkisinde Banon ve ark. (2012) tuz stresini incelemișlerdir. Bu araștırmaların sonucunda yüksek $\mathrm{Na}^{+}, \mathrm{Cl}, \mathrm{Ca}^{+2}, \mathrm{Mg}^{+2}$ konsantrasyonları doğrudan bitkide verim ve kaliteyi olumsuz olarak etkilediği konusunda önemli sonuçlar elde edilmiștir.

Sorumlu Yazar: snakaroglu@adu.edu.tr Geliș Tarihi: 14 Kasım 2017

Kabul Tarihi: 04 Haziran 2018 
Bașta yüksek $\mathrm{Na}^{+}$konsantrasyonun toprakta gözenekliği ve geçirgenliği azaltarak toprak yapısını bozmaktadır (Taiz ve Zeiger, 2008). Ortaya çıkan tuz stresi toprağın gözeneklerini azaltıp hidroelektrik iletkenliğini bozarak toprağın fiziksel yapısını olumsuz etkilemekte, toprakta düșük su potansiyeli yaratarak bitkinin besin, su ve mineral alınımını güçleștirmekte, neden olduğu iyon toksitesiyle de bitkilerde metabolik bozukluklara yol açarak bitkinin büyüme ve gelișmesini baskılamaktadır. Ayrıca tuz stresi, proteinlere, lipidlere ve nükleik asitlere saldıran reaktif oksijen türlerinin (ROS) olușmasına da neden olmaktadır (Mittler, 2002). Çilek bitkilerinde de zayıf bitkisel büyüme, küçük meyve üretimi ve yapraklar üzerinde leke olușumu ile toprakta tuz birikimi ve sulama suyu tuz konsantrasyonunun arasında bir ilișki bulunmaktadır (Kepenek ve Koyuncu, 2002; D'Anna ve ark., 2003; Keutgen ve Keutgen, 2003; Saied ve ark., 2005).

Tarımsal sulama da kullanılan suyun kalitesi sadece tarımda yüksek verim alınması amacıyla kullanılan gübre, pestisit, herbisit ve hormonların suya karıșması ile düșmemekte aynı zamanda evsel ve endüstriyel atık suların da sulama suyuna karıșması sonucunda da azalmaktadır. Bu kimyasal kirlenmeler sonucu çevre ve insan sağlığı da risk altına girmektedir (Crohn ve Bianchi, 2008; Jawahar ve Ringler, 2009). Su azlığı çeken bir ülke konumunda olan Türkiye'nin yüzey ve yeraltı sularında günümüzde gözlenen kirlenmeler bu șekilde devam ederse, 25-30 yıl sonra geri dönüșümü olmayan sorunlar ortaya çıkaracaktır (Akın ve Akın, 2007). Önemli tarım alanlarımızın sulanmasında rol oynayan Büyük Menderes endüstriyel atık suların kontrolsüz ve bilinçsiz bırakılmalarıyla kirlenmekte olan su kaynaklarımız arasında yer almaktadır. Türkiye'de arıtma tesisi olan sanayi kurulușlarının oranının az olușu veya sanayi kurulușlarının çoğunun arıtma tesislerinin olmaması ya da var olan arıtma tesislerinin etkin olarak ișletilememesi gibi nedenlerle yüzey sularında kirlenmenin boyutları gün geçtikçe artmaktadır (Burak ve ark., 1997; Yıldırım ve ark., 2004; Akman ve ark., 2004). Delibacak ve ark. (2002) endüstriyel, evsel atıklar ve yoğun tarımsal faaliyetlerle kirlenmiș olan Gediz nehrinin suyunda $N, P$, $\mathrm{K}, \mathrm{Mg}, \mathrm{Fe}$ ve $\mathrm{Zn}$ seviyelerinin düșük ve orta değerler arasında olduğunu, bu suyla sulanan topraklarda $\mathrm{Fe}, \mathrm{Zn}$, $\mathrm{Mn}, \mathrm{B}, \mathrm{Cd}, \mathrm{Ni}, \mathrm{Cr}$ ve $\mathrm{Co}$ seviyelerinin ise yüksek olduğunu saptamıșlardır. Șahin ve ark. (201 I)'de Ușak ili, Dokuz Sele Çayından alınan suyun, mısır (Zea mays), ayçiçeği (Helianthus annus), fasulye (Phaseolus vulgaris) ve yemlik pancar (Beta vulgaris ssp. Crassa) tohumlarının çimlenmesini ve bitki gelișimini olumsuz etkilediğini, bu nedenle bu suyun sulama suyu olarak kullanılmaması gerektiğini bildirmișlerdir. Özbay ve ark. (2013) Mersin
Ili'nin önemli akarsularından birisi olan Berdan Çayı'nda mevsimsel olarak toplanan sediment örneklerinde en fazla ağır metal birikiminin demirde (18521.91 $\mu \mathrm{g} / \mathrm{g}$ ) olduğunu saptamıșlardır. Bununla birlikte tarımsal alanlarda yaygın olarak kullanılan etkin maddesi $\mathrm{Cu}$ ve $\mathrm{Mn}$ olan pestisitler ile $\mathrm{Cr}, \mathrm{Ni}$ ve $\mathrm{Mn}$ içeriği yüksek suni gübrelerin yağmurlar ve insan aktiviteleri sonucu çaya karıștığını, ilçede yer alan maden ocakları nedeniyle $\mathrm{Pb}$, $\mathrm{Zn}$ ve $\mathrm{Cr}$ da yüksek birikim gösterdiğini bildirmișleridir. Kaçan ve Ülkü (20/3) Su Kirliliği ve Kontrolü Yönetmeliği'ne göre Gümüșçay ve Çürüksu derelerinin organik madde konsantrasyonu bakımından IV. sınıf, Büyük Menderes Nehri'nin (Sarayköy Köprüsü'nde) ise III. sınıf su kalitesinde olduğunu bildirmișlerdir.

Çilek üretimi susuz yapılamayacak bir tarım șeklidir. Çilek üretiminde istenilen kalite ve verime ulașmak için gerekli bitki besin elementleri sağlanmalıdır. Besin elementleri toprakta yeterli miktarda bulunmadığı, yavaș bir biçimde elverișli hale geçtiği ya da diğer besin elementleri ile dengeli olmadığı durumlarda bitki besleme ile ilgili sorunlar ortaya çıkmaktadır. Tuzluluk, alkalilik ve bor besin elementlerin bitki tarafından alınmasını olumsuz yönde etkileyen abiyotik faktörlerdir.

Büyük Menderes havzası içerisinde yer alan, mikro klima özelliğine sahip olan Sultanhisar ilçesinin tarım alanlarının sulanmasında Akçay Sağ Sahil Sulama Birliği ile Nazilli Sağ Sahil Sulama Birliği'nden sağlanan su önemli rol oynamaktadır. Nazilli Sağ Sahil Sulama Birliği’nden su kullanan çilek üreticileri son yıllarda çilek bitkilerinde kurumalarının arttıı̆ını belirtmișlerdir. Çilek üretiminde, hem Aydın ilinde hem de Türkiye genelinde, gerek ürün kalitesi ve gerek üretim miktarı açısından söz sahibi olan Sultanhisar ilçesinde, ürün kayıplarının meydana gelișinde su kalitesinin bir etkisi olup olmadığının araștırılması önemlidir. Çilekte ve diğer bitkilerde görülen bu kurumalar üreticinin ekonomik gücünü de olumsuz etkilemektedir. Nazilli Sağ Sahil Sulama Birliği'nin su kalitesinin bitkisel üretim üzerine etkisi konusunda daha önce yapılmıș bir araștırma veya saha çalıșması bulunmamaktadır. $\mathrm{Bu}$ kanal suyunun tarımda kullanılmasının toprak ve bitki bakımından olușturduğu sorunun boyutu hakkında daha fazla bilgi edinilmesi önemlidir.

Bu çalıșma, sulama suyu olarak Nazilli Sağ Sahil Sulama Birliği kanalından alınan suyun çilek bitkilerinin besin maddesi içeriği ve meyve kalitesi üzerine etkilerini araștırmak amacıyla yürütülmüștür.

\section{MATERYAL ve YÖNTEM}

Çalıșma, 2016 yilında, Adnan Menderes Üniversitesi, Sultanhisar Meslek Yüksekokulu uygulama bahçesinde bulunan plastik örtülü tünel serada yürütülmüștür. Çalıșma materyalini Sultanhisar ilçesinde en çok 
yetiștiriciliği tercih edilen Rubygem çilek çeșidi olușturmuștur. Bitkiler I/3 bahçe toprağı, I/3 yanmıș hayvan gübresi, I/3 dere kumundan olușan yetiștirme ortamının içine konulduğu $35 \times 50 \times 20 \mathrm{~cm}$ kasalarda yetiștirilmiștir. Yetiștirme ortamında kullanılan bahçe
AKAROĞLU Ş N, SEFEROĞLU S toprağı ile ilgili analiz sonuçları Çizelge I'de verilmiștir. Araștırmanın yürütüldüğü Aydın Sultanhisar İlçesi'nin Șubat 2016-Haziran 2016 aylarına ait bazı iklim değerleri Çizelge 2'de verilmiștir.

Çizelge I. Yetiștirme ortamında kullanılan toprağın analiz sonucu

\begin{tabular}{lcccccccc}
\hline Bünye & Kum (\%) & Kil (\%) & Silt (\%) & $\begin{array}{c}\text { Toplam } \\
\text { Tuz (\%) }\end{array}$ & pH & $\begin{array}{c}\text { Kireç } \\
(\%)\end{array}$ & Organik Madde (\%) \\
\hline Kumlu-tınlı & 55.30 & 29.30 & 15.40 & 0.0163 & 7.40 & 1.73 & 1.69 \\
\hline
\end{tabular}

Çizelge 2. Sultanhisar İlçesinin 2016 yılı Șubat-Haziran ayları arasındaki bazı iklim verileri ile uzun yıllara ait aylara göre bazı iklim değerleri

\begin{tabular}{|c|c|c|c|c|c|}
\hline \multicolumn{6}{|c|}{ Aylar (2016) } \\
\hline Meteorolojik Parametreler & Șubat & Mart & Nisan & Mayıs & Haziran \\
\hline Aylık Ort. Sıcaklık $\left({ }^{\circ} \mathrm{C}\right)$ & 12.6 & $12.4 \mathrm{C}$ & 18.6 & 20.0 & 27.3 \\
\hline Aylık Ort. Oransal Nem (\%) & 73.1 & 71.0 & 57.6 & 58.4 & 43.8 \\
\hline Aylık Toplam Yağıș $\left(\mathrm{mm}=\mathrm{kg}: \mathrm{m}^{2}\right)$ & 43.8 & 130.4 & 5.4 & 24.4 & 2.2 \\
\hline \multicolumn{6}{|c|}{ Aylar (1940-20I7 arası Uzun Yıllar Aylık Ortalama)* } \\
\hline Aylık Ort. Sıcaklık $\left({ }^{\circ} \mathrm{C}\right)$ & 9.3 & 11.7 & 15.9 & 20.9 & 25.8 \\
\hline Aylık Toplam Yağıș (mm=kg:m²) & 93.6 & 70.9 & 48.8 & 35.2 & 13.7 \\
\hline
\end{tabular}

Kaynak: Devlet Meteoroloji İșleri Bölge Müdürlüğü Kayıtları, Aydın (Anonim, 20l8a)

*Kaynak: Devlet Meteoroloji İșleri Bölge Müdürlüğü, www.mgm.gov.tr Erișim tarihi : 18.05.2018 (Anonim, $2018 \mathrm{~b})$

Araștırmada sulama suyu olarak, Aydın ili Sultanhisar İlçesi'nde çilek alanlarının büyük bir bölümünün sulanmasında rol oynayan Nazilli Sağ Sahil Sulama Birliği kanalından alınan su örnekleri ve kontrol grubu olarak șebeke suyu kullanılmıștır. Alınan su örneklerinde analizler, Adnan Menderes Üniversitesi Ziraat Fakültesi Toprak Bilimi ve Bitki Besleme Bölümüne ait laboratuvarda yapılmıștır. Su örneklerinde buharlașma kalıntısı, erimiș katı madde, geçici sertlik, toplam sertlik, $\mathrm{pH}, \mathrm{EC}, \mathrm{K}^{+}, \mathrm{Ca}^{+2}, \mathrm{Na}^{+}, \mathrm{SAR}, \mathrm{Cl}, \mathrm{CO}_{3}^{-2}, \mathrm{HCO}_{3}^{-} \mathrm{B}$, analizleri yapılmıștır (Tuncay, 1994). Meyve kalitesini belirlemek amacıyla; meyve boyu, meyve çapı, meyve ağırlığı, suda çözünebilir kuru madde miktarı, meyvelerin delinme direnci ölçümleri yapılmıștır.

Çalıșma, tesadüf parselleri deneme desenine göre 3 tekerrürlü ve her tekerrürde 6 bitki olacak șekilde yürütülmüștür. İstatistiki analizler SPSS paket programı kullanılarak gerçekleștirilmiștir.

\section{BULGULAR ve TARTIȘMA}

Nazilli Sağ Sahil Sulama Birliği'nden 2016 yılında Mart, Nisan, Mayıs ve Haziran aylarında 4 kez su örneği alınmıș olup bu suların aylara göre $\mathrm{pH}$, EC, buharlaștırma kalıntısı, erimiș madde miktarı, geçici sertlik, toplam sertlik, SAR analizleri yapılmıștır. Su analiz sonuçları Çizelge 3'de verilmiștir. Araștırmada kontrol grubu sulama suyu olarak kullanılan șebeke suyunun $\mathrm{pH}$, EC, buharlaștırma kalıntısı, erimiș madde miktarı, geçici sertlik, toplam sertlik, SAR analiz sonuçları ise Çizelge 4' de verilmiștir.

Çizelge 3. Sağ Sahil Sulama Birliği'nden alınan su örneklerinin buharlaștırma kalıntısı, erimiș madde miktarı, pH, EC, geçici sertlik, toplam sertlik, SAR analiz sonuçları.

\begin{tabular}{|c|c|c|c|c|c|c|c|c|}
\hline $\begin{array}{l}\text { Örnek } \\
\text { Alma } \\
\text { Zamanı }\end{array}$ & $\begin{array}{l}\text { Buharlașma } \\
\text { kalıntısı } \\
(\mathrm{mg} / \mathrm{l})\end{array}$ & $\begin{array}{l}\text { Erimiș katı } \\
\text { maddeler } \\
(\mathrm{mg} / \mathrm{l})\end{array}$ & $\mathrm{pH}$ & $\begin{array}{l}\mathrm{EC} \\
(\mu \mathrm{S} / \mathrm{cm})\end{array}$ & $\begin{array}{l}\text { Geçici } \\
\text { sertlik } \\
\text { (Alman) }\end{array}$ & $\begin{array}{l}\text { Toplam } \\
\text { sertlik } \\
\text { (Alman) }\end{array}$ & $\begin{array}{l}\text { SAR } \\
\text { (me/l) }\end{array}$ & Sinif \\
\hline Mart & 320 & 240 & 6.93 & 340 & 15.12 & 10.08 & 0.05 & $\mathrm{C}_{2} \mathrm{~S}_{\mathrm{I}}$ \\
\hline Nisan & 400 & 360 & 7.74 & 644 & 16.80 & 12.32 & 0.19 & $\mathrm{C}_{2} \mathrm{~S}_{1}$ \\
\hline Mayıs & 320 & 240 & 7.63 & 1495 & 20.44 & 16.80 & 0.23 & $\mathrm{C}_{3} \mathrm{~S}_{1}$ \\
\hline Haziran & 360 & 280 & 8.03 & 1434 & 20.72 & 17.92 & 0.28 & $\mathrm{C}_{3} \mathrm{~S}_{\mathrm{I}}$ \\
\hline Ortalama & 350 & 280 & 7.58 & 978.3 & 18.27 & 14.28 & 0.19 & \\
\hline
\end{tabular}


Çizelge 4. Kontrol grubu su örneğinin buharlaștırma kalıntısı, erimiș madde miktarı, pH, EC, geçici sertlik, toplam sertlik, SAR analiz sonuçları.

\begin{tabular}{llllllll}
\hline $\begin{array}{l}\text { Buharlașma } \\
\text { Kalıntısı } \\
(\mathrm{mg} / \mathrm{l})\end{array}$ & $\begin{array}{l}\text { Erimiș Katı } \\
\text { maddeler } \\
(\mathrm{mg} / \mathrm{l})\end{array}$ & $\mathrm{pH}$ & $\begin{array}{l}\mathrm{EC} \\
(\mu \mathrm{S} / \mathrm{cm})\end{array}$ & $\begin{array}{l}\text { Geçici Sertlik } \\
(\text { Alman })\end{array}$ & $\begin{array}{l}\text { Toplam } \\
\text { Sertlik } \\
(\text { Alman })\end{array}$ & $\begin{array}{l}\text { SAR } \\
(\mathrm{me} / \mathrm{l})\end{array}$ & $\begin{array}{c}\text { Sınıf } \\
\end{array}$ \\
\hline 580 & 360 & 7.45 & 348 & 21.28 & 19.06 & $0.1 \mathrm{I}$ & $\mathrm{C}_{2} \mathrm{~S}$ । \\
\hline
\end{tabular}

Nazilli Sağ Sahil Sulama Birliği'nden alınan sulama sularında $\mathrm{pH}^{\prime}$ nın Mart ayında hafif asit karakterli iken, Nisan, Mayıs, Haziran aylarında hafif alkali reaksiyon gösterdiği, EC değerlerinin de benzer bir artıș göstererek suyun fazla tuzlu su $\left(\mathrm{C}_{3}\right)$ sınıfına girdiği saptanmıștır. Aydın ve Seferoğlu (1999) ile Öztürk ve Seferoğlu (20I0)'nun yaptıkları çalıșmalarda Aydın ili sulama sularının pH'sının hafif alkali ve alkali olduğunu bildirmișlerdir. Kanal suyundan Mayıs ve Haziran aylarında alınan su örnekleri $C_{3}$ sınıfında olup, $C_{3}$ sınıfı sular Thorne ve Peterson (1954)'e göre fazla tuzlu su sınıfında yer almaktadır.

Kontrol grubu bitkilerinin sulamasında kullanılan suyun $\mathrm{pH}$ ve EC değerlerinin Nazilli Sağ Sahil Sulama Birliği'nden alınan sulama suyu değerlerine göre daha düșük olduğu ve sınıf olarak az tuzlu $\left(C_{2}\right)$ sulama suyu sınıfına girdiği görülmektedir. Nazilli Sağ Sahil Sulama Birliğinden alınan su örneklerinde anyon ve katyon analizleri Çizelge 5'te ve kontrol grubu sulama suyunun katyon ve anyon analiz sonuçları Çizelge 6'de verilmiștir.

Çizelge 5. Kanal Suyunun katyon ve anyon analiz sonuçları.

\begin{tabular}{|c|c|c|c|c|c|c|c|}
\hline \multirow{2}{*}{$\begin{array}{l}\text { Örnek Alma } \\
\text { Tarihi }\end{array}$} & \multicolumn{7}{|c|}{ Anyon ve Katyonlar } \\
\hline & $\begin{array}{l}\mathrm{K}^{+} \\
(\mathrm{me} / \mathrm{l})\end{array}$ & $\begin{array}{l}\mathrm{Ca}^{+2} \\
(\mathrm{me} / \mathrm{l})\end{array}$ & $\mathrm{Na}^{+}(\mathrm{me} / \mathrm{l})$ & $\begin{array}{l}\mathrm{CO}_{3}^{-2} \\
(\mathrm{me} / \mathrm{l})\end{array}$ & $\begin{array}{l}\mathrm{HCO}_{3-}^{-} \\
(\mathrm{me} / \mathrm{l})\end{array}$ & $\begin{array}{l}\mathrm{Cl}^{-} \\
(\mathrm{me} / \mathrm{l})\end{array}$ & $\begin{array}{l}\mathrm{B} \\
\mathrm{Ppm}\end{array}$ \\
\hline Mart & 0.04 & 0.23 & 0.04 & 0 & 5.33 & 0.55 & 0.09 \\
\hline Nisan & 0.01 & 0.28 & 0.22 & 0 & 3.95 & 1.36 & 0.20 \\
\hline Mayıs & 0.02 & 0.5 & 0.43 & 0.10 & 7.70 & 2.18 & 0.41 \\
\hline Haziran & 0.03 & 0.55 & 0.49 & 0.30 & 7.40 & 2.73 & 0.36 \\
\hline Ortalama & 0.03 & 0.39 & 0.30 & 0.18 & 6.10 & 1.71 & 0.27 \\
\hline
\end{tabular}

Çizelge 6. Kontrol grubu bitkilerin sulamasında kullanılan suyun katyon ve anyon analiz sonuçları

\begin{tabular}{lllllll}
\hline $\begin{array}{l}\mathrm{K}^{+} \\
(\mathrm{me} / \mathrm{l})\end{array}$ & $\begin{array}{l}\mathrm{Ca}^{+2} \\
(\mathrm{me} / \mathrm{l})\end{array}$ & $\begin{array}{l}\mathrm{Na}^{+} \\
(\mathrm{me} / \mathrm{l})\end{array}$ & $\begin{array}{l}\mathrm{CO}^{-2} \\
(\mathrm{me} / \mathrm{l})\end{array}$ & $\begin{array}{l}\mathrm{HCO}_{3}^{-} \\
(\mathrm{me} / \mathrm{l})\end{array}$ & $\begin{array}{l}\mathrm{Cl} \\
(\mathrm{me} / \mathrm{l})\end{array}$ & $\begin{array}{l}\mathrm{B} \\
\mathrm{Ppm}\end{array}$ \\
\hline $0.0 \mathrm{I}$ & $0.5 \mathrm{I}$ & 0.15 & 0 & 7.40 & 1.18 & 0.05
\end{tabular}

Çizelge 5'e göre kanal suyunda kalsiyum, sodyum, bikarbonat, klor ve bor miktarlarının aylara göre artıș gösterdiği görülmektedir. Öztürk ve Seferoğlu (20l0) Söke ovasından örnekleme için 24 adet kuyudan aldıkları su örneklerinde de Haziran ayına göre Ağustos ayında alınan su örneklerinde sodyum, klor, karbonat ve bikarbonat içeriklerinin arttığını, $\mathrm{Na}$ ve buna bağlı olarak
SAR değerlerinin yüksek olduğunu tespit etmișlerdir. Bundan dolayı bu kuyu sularının sulama amacıyla kullanımında dikkatli olunmasını önermișlerdir.Çilek bitkisinin yetișme dönemi içerisinde kullanılan sulama suyu kalitesine göre bitkinin topraktan kaldırdığı makro ve mikro besin maddeleri miktarı Çizelge 7'te verilmiștir.

Çizelge 7. Kontrol ve kanal suyu ile sulanan bitkilerin yapraklarındaki makro ve mikro besin elementlerinin analiz sonuçları

\begin{tabular}{llllllllllll}
\hline \multirow{2}{*}{ Uygulama } & $\mathrm{N}$ & $\mathrm{P}$ & $\mathrm{K}$ & $\mathrm{Ca}$ & $\mathrm{Mg}$ & $\mathrm{Na}$ & $\mathrm{Fe}$ & $\mathrm{Zn}$ & $\mathrm{Cu}$ & $\mathrm{Mn}$ & $\mathrm{B}$ \\
& $(\%)$ & $(\%)$ & $(\%)$ & $(\%)$ & $(\%)$ & $(\%)$ & $\mathrm{Ppm}$ & $\mathrm{Ppm}$ & $\mathrm{Ppm}$ & $\mathrm{Ppm}$ & $\mathrm{Ppm}$ \\
\hline Kontrol & $\mathrm{I} .96$ & 0.24 & 1.86 & 3.91 & 7.86 & 0.01 & $70.33^{*}$ & 31.67 & 9.00 & 96.33 & $84.67^{*}$ \\
Kanal & $\mathrm{I} .75$ & 0.24 & 1.66 & 4.00 & 8.36 & 0.02 & $14.33^{*}$ & 35.33 & 14.33 & 104.00 & $112.33^{*}$ \\
\hline
\end{tabular}

\section{(*) $\mathbf{P}<0.05$ düzeyinde önemlidir.}

Atık ve Çizelge 7'e göre, kanal suyu ile sulanan bitkilerin yapraklarında kontrol bitkilerin yapraklarına göre istatistiksel olarak önemli olmamakla birlikte $\mathrm{Ca}, \mathrm{Mg}, \mathrm{Na}$, $\mathrm{Zn}, \mathrm{Cu}$ ve $\mathrm{Mn}$ miktarı daha fazla bulunduğu saptanmıștır. Kanal suyu ile sulanan bitkilerde bu elementlerin birikimi kontrol grubu bitkilerine göre beslenme ve metabolizmaları üzerine olumsuz etki yapmıștır. Bununla birlikte kanal suyu ile sulanan bitkilerin bor içeriğinin
( I 12.33 ppm) șebeke su ile sulananlara (84.67 ppm) göre istatiksel olarak önemli olduğu saptanmıștır. Yurtseven ve ark. (2000) brokoli bitkisinde (Brassica oleracea botrytis) toplam mineral madde birikiminin bir göstergesi olan toplam kül analiz değerlerinde, sulama suyu tuzluluğunun artmasına paralel olarak, toplam kül değerlerinin de arttığını, buna bağlı olarak bitki vejetatif aksamındaki mineral madde birikiminin fazlalaștığını 
saptamıșlardır. Yakıt ve Tuna (2006) yaptıkları çalıșma sonucunda mısır bitkisinde tuzluluk stresine bağlı olarak yaprak ve köklerde $\mathrm{Na}^{+}$içeriğinin arttığını $\mathrm{Ca}^{+2}$ ve $\mathrm{K}^{+}$gibi katyonların içeriğinin azaldığını bildirmișlerdir.

Delibacak ve ark. (2002)'nın endüstriyel, evsel atıklar ve yoğun tarımsal faaliyetlerle kirlenmiș olan Gediz nehrinin suyuyla sulanan tarımsal arazilerin yüzde \%83'ünde borun fitotoksik seviyenin üzerinde olduğunu saptamıșlardır. Kanal suyu ile sulanan bitkilerde demir miktarının kontrol grubu bitkilere göre istatistiki olarak önemli olmakla birlikte çok düșük olduğu saptanmıștır. Ashraf (2004)'e göre tuzlu olmayan koșullarda yüksek bitkilerin hücre sitozolü 100 ile $200 \mathrm{mM} \mathrm{K} \mathrm{K}^{+}$ve I ile $10 \mathrm{mM} \mathrm{Na}{ }^{+}$ içermektedir. Tuzlu koșulların olușturduğu bu iyonik ortamda pek çok enzim optimumda çalıșırken, toprakta değișebilir $\mathrm{Na}^{+}$, yüksek $\mathrm{Na}^{+} / \mathrm{K}^{+}$ve $\mathrm{Na}^{+} / \mathrm{Ca}^{+}$oranları meydana gelmektedir. Bu koșullar altında bitkiler bu tip topraklarda yüksek miktarlarda $\mathrm{Na}^{+}$iyonu alırken, $\mathrm{K}^{+}$ve $\mathrm{Ca}^{+}$alımları önemli ölçüde azaltmaktadır. Araștırmamızda çilek bitkilerinin yapraklarındaki $\mathrm{K}^{+}$ve $\mathrm{Na}^{+}$miktarları toplam ağırlığa göre tespit edilmiștir. Buna göre kanal suyu ile beslenen bitkilerin yapraklarındaki $\mathrm{K}^{+} / \mathrm{Na}^{+}$oranı, kontrol grubundaki bitkilerin yapraklarındaki $\mathrm{K}^{+} / \mathrm{Na}^{+}$ oranına göre düșük olduğu tespit edilmiștir (Çizelge 8).

Çizelge 8. Kontrol ve kanal suyu ile sulanan bitkilerin yapraklarındaki $\mathrm{K}^{+} / \mathrm{Na}^{+}$oranları.

\begin{tabular}{llll}
\hline Uygulamalar & $\mathrm{K}^{+}(\mu \mathrm{g} / \mathrm{mg}$ T.A $)$ & $\mathrm{Na}^{+}(\mu \mathrm{g} / \mathrm{mg} \mathrm{T} . \mathrm{A})$ & $\mathrm{K}^{+} / \mathrm{Na}^{+}$ \\
\hline Kontrol & $0.476^{*}$ & $0.0004^{*}$ & $1.19^{*}$ \\
\hline Kanal & $0.425^{*}$ & $0.0008^{*}$ & $0.53^{*}$ \\
\hline
\end{tabular}

(*) $\mathbf{P}<0.05$ düzeyinde önemlidir.

Çizelge 8'e göre kullanılan su kaynağı bakımından uygulamalar arasında istatistiki olarak önemli bir fark vardır. Taiz ve Zeiger (2008)'e göre yeterli miktarlarda hem $\mathrm{K}^{+}$hem de $\mathrm{Ca}^{+}$hücre zarının bütünlüğünü ve ișleyișini sürdürmesi için gereklidir. Bu durum enzimleri etkinsizleștirmekte ve protein sentezi engellemektedir. $\mathrm{Na}+$ konsantrasyonu yüksek olduğunda, bu iyon kök tüyü hücrelerinin plazma zarında $\mathrm{Ca}^{+2}$ 'un yerini alabilmektedir. Bunun sonucunda plazma zarının geçirgenliği değișmekte ve $\mathrm{K}^{+}$hücrelerden sızmaktadır. Kacar ve ark. (2002)'e göre $\mathrm{NaCl}$ 'un yüksek olduğu topraklarda $\mathrm{NO}_{3}^{-}, \mathrm{K}^{+}$ve $\mathrm{Ca}^{+2}$ alınımı önemli derecede azalmaktadır. İyon regülasyonu, bitkilerin tuza toleransının belirlenmesinde önemli bir faktördür. Tuzlu koșullarında bitki genotiplerinin dokularında düșük $\mathrm{Na}^{+}$ ve $\mathrm{Cl}^{-}$alımı yanında daha yüksek oranlarda $\mathrm{K}^{+}$ve $\mathrm{Ca}^{+2}$ seviyelerinin olușturulması toleransın anahtar mekanizmalarını olușturmaktadır. Genel olarak tuz stresine toleransı olan bitkiler dokularında daha yüksek $\mathrm{K}^{+} / \mathrm{Na}^{+}$oranını olușturma kabiliyetine sahiptirler. Özellikle bitkilerin tuz stresine toleransını belirlemek amacı ile olușturulan tarama çalıșmalarında, farklı bitki organlarında $\mathrm{K}+/ \mathrm{Na}^{+}$ve $\mathrm{Ca}^{+2} / \mathrm{Na}^{+}$oranları ile dokulardaki $\mathrm{Na}^{+}$konsantrasyonlarının belirlenmesi önemli bir parametre olarak karșımıza çıkmaktadır. Bitkilerin yüksek tuzlu koșullar altındaki yüksek $\mathrm{K}^{+} / \mathrm{Na}^{+}$seçicilikleri tuza toleransta önemli bir seleksiyon kriteri olarak önerilmektedir (Ashraf, 2004). Üzal ve Yıldız (20I4), farklı çilek çeșitleri üzerine $2000 \mathrm{mg} / \mathrm{L} \quad \mathrm{NaCl}$ uygulamasının etkilerini inceledikleri çalıșmalarında tuza toleranslı çeșitlerin $\mathrm{K}^{+} / \mathrm{Na}^{+}$oranını yüksek olduğunu, buna karșın tuz toleransı düșük olan çeșitlerde bu oranı düșük olduğunu saptamıșlardır. Tuza toleranslı çeșitlerin yapraklarındaki zararlanmanın tuza hassas çeșitlere göre daha az olduğunu tespit etmișlerdir. Süyüm (20I I) yaptığı araștırmada 65 adet karpuz genotipinin tuzluluk ve kuraklığa tolerans bakımından geniș bir varyasyon gösterdiğini bildirmiștir.

Kanal suyu ve șebeke suyu ile sulanan bitkilerden elde edilen meyvelerin meyve en, boy ve ağırlık ile toplam suda erir kuru madde miktarı (TSEM) ve meyve eti sertliği ile ilgili sonuçlar Çizelge 9'da verilmiștir. Çizelge 9'a göre kontrol ve kanal suyu uygulaması yapılan bitkilerden elde edilen meyvelerdeki farklılıklar istatistiki olarak önemli değildir. Diğer taraftan kanal suyu ile sulanan bitkilerden ortalama olarak daha iri meyveler elde edilirken, toplam suda erir kuru madde (TSEM) bakımından daha düșük değere sahip meyveler elde edilmiștir. Bununla birlikte kanal suyu ile sulanan bitkilerde Mayıs ve Nisan aylarında elde edilen meyvelerde kontrol grubuna göre meyve eni, meyve boyu ve ağırlığında istatistiki olarak önemli olmamakla birlikte azalmalar meydana gelmiștir. Ekmekçi ve ark. (2005)'in bildirdiğine göre, Yurtseven ve ark. (1996) yetiștirilen bitkinin veriminde görülecek azalmaların, çözeltinin konsantrasyonuna bağlı olduğu kadar, bitkinin tuza dayanımıyla de ilgili olduğunu belirtmișlerdir. Tuza dayanımı fazla olan bitkiler yüksek tuzluluklarda bile verimde önemli azalmalar olușturmazken, tuza dayanımı fazla olmayan bitkiler düșük tuzluluklarda bile önemli azalmalar gösterebileceğini belirtmișlerdir. Kanal suyu ve șebeke suyu ile sulanan bitkilerden elde edilen verim ile ilgili sonuçlar Çizelge 10'da verilmiștir. Çizelge 10'na göre kanal suyu ile sulanan bitkilerde kontrole göre istatiksel olarak önemli olmamakla birlikte toplamda daha yüksek verim elde edilmiștir. 
Çizelge 9. Kontrol ve kanal suyu ile sulanan bitkilerin meyve analiz sonuçları

\begin{tabular}{|c|c|c|c|c|c|c|c|}
\hline Uygulama & Aylar & $\begin{array}{l}\text { Minimum en } \\
(\mathrm{mm})\end{array}$ & $\begin{array}{l}\text { Maksimum } \\
\text { en }(\mathrm{mm})\end{array}$ & $\begin{array}{l}\text { Meyve } \\
\text { boyu }(\mathrm{mm})\end{array}$ & $\begin{array}{l}\text { Meyve } \\
\text { ağırlığı (g) }\end{array}$ & $\begin{array}{l}\text { TSEM } \\
(\%)\end{array}$ & $\begin{array}{l}\text { Meyve eti } \\
\text { sertliği }(\mathrm{kg})\end{array}$ \\
\hline \multirow[t]{3}{*}{ Kontrol } & Nisan & 25.55 & 29.45 & 33.76 & 13.46 & 6.92 & 1.64 \\
\hline & Mayıs & 27.00 & 30.38 & 32.30 & $14.1 \mid$ & 8.34 & 0.85 \\
\hline & Haziran & 23.44 & 26.96 & 28.87 & 10.44 & 7.81 & 0.76 \\
\hline Ortalama & & 25.33 & 28.93 & 31.64 & 12.67 & 7.69 & 1.08 \\
\hline \multirow[t]{3}{*}{ Kanalsuyu } & Nisan & 30.09 & 35.29 & 40.31 & 21.60 & 6.51 & 1.55 \\
\hline & Mayıs & 26.07 & 30.23 & 31.81 & 14.13 & 7.40 & 0.94 \\
\hline & Haziran & 22.88 & 27.23 & 27.87 & 10.00 & 8.04 & 0.67 \\
\hline \multirow[t]{2}{*}{ Ortalama } & & 26.34 & 30.91 & 33.33 & 15.24 & 7.32 & 1.05 \\
\hline & & Ö.D. & Ö.D. & Ö.D. & Ö.D. & Ö.D. & Ö.D. \\
\hline
\end{tabular}

Çizelge I0. Kanal suyu ve șebeke suyu ile sulanan bitkilerden elde edilen verim (gram/bitki)

\begin{tabular}{|c|c|c|c|c|}
\hline \multirow{2}{*}{ Uygulama } & \multicolumn{3}{|l|}{ Aylar } & \multirow{2}{*}{$\begin{array}{l}\text { Toplam } \\
\text { Verim }\end{array}$} \\
\hline & Nisan & Mayıs & Haziran & \\
\hline Kontrol & 111,69 & 107,263 & 234,897 & 453,85 \\
\hline Kanal & 114,38 & 179,967 & 218,96 & $5|3,3|$ \\
\hline$P<0.05$ & Ö.D & Ö.D. & Ö.D & Ö.D \\
\hline
\end{tabular}

Ancak kanal suyu ile sulanan bitkilerde Haziran ayında bitki ölümleri meydana gelmiș olup, çalıșmanın sonunda kanal suyu ile sulanan bitkilerin tamamı ölmüștür (Șekil I ve Șekil 2).

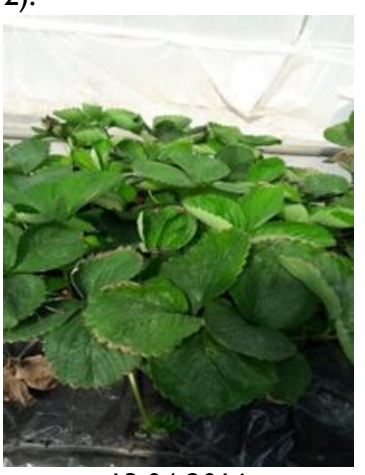

13.042016

Șekil I. Kontrol grubu bitkilerin aylara göre gelișimi

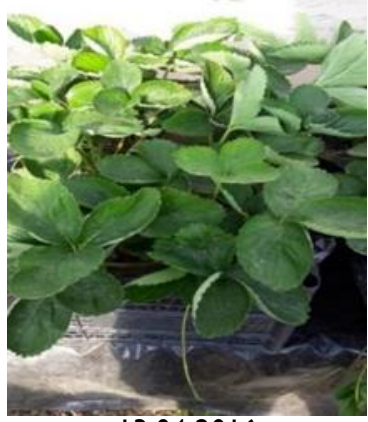

13.042016

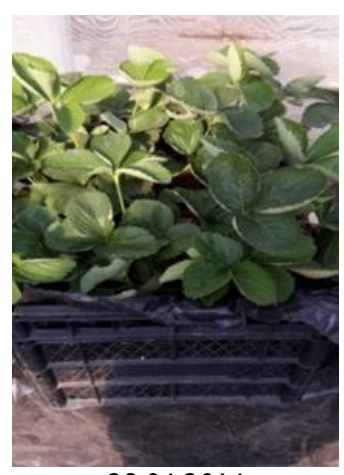

29.06.2016

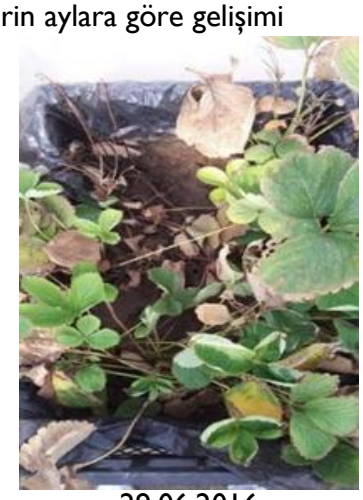

29.06.2016
Șekil 2. Kanal suyu ile sulanan bitkilerin aylara göre gelișimi
Kanal suyu ile sulanan bu bitkilerin yetiștiği harç içerisinde yeterli miktarda su bulunmasına rağmen bitkiler fizyolojik kuraklık sonucu ölmüștür. Ayyıldız (1990)'a göre bitkiler fizyolojik kuraklık durumunda yüksek osmotik basınç nedeniyle topraktaki sudan yararlanamamaktadır. Bitkilerde fizyolojik kuraklığın meydana gelișinde tuzlu ortamların çoğunda büyük bir miktarda su bulunmaktadır, ancak bu ortamlarda su potansiyeli düșüktür. Düșük su potansiyelinin yanında $\mathrm{Cl}^{-}$ya da $\mathrm{SO}_{4}{ }^{-2}$ olmak üzere hücrede özellikle $\mathrm{Na}^{+}$, $\mathrm{Cl}^{-}$ya da $\mathrm{SO}_{4}^{-2}$ gibi iyonlar zararlı konsantrasyonlarda birikince spesifik iyon toksitesi sorunu ortaya çıkmaktadır (Taiz ve Zeiger2008). Turhan ve Eriș (2006) uzun süre tuz uygulaması sonucunda Camarosa çilek çeșidinin ve Chandler çeșidine göre tuza daha dayanıklı olduğunu saptamıșlardır.

Camarosa çeșidinde Chandler çeșidine göre tuz konsantrasyonuna bağlı stoma iletkenliği ve transpirasyonda görülen azalmanın daha az olmasını, tuza toleransta çeșitlerin sahip olduğu adaptasyon mekanizma farlılıklarından kaynaklandığı sonucuna varmıșlardır. Rubygem çeșidinin kanal suyunda artan tuza karșılık bitkilerde ölüm gerçekleșinceye kadar süreç içerisinde çiçeklenmeye ve meyve verimine devam etmesi tuza toleransa karșı gösterdiği adaptasyon mekanizması ile ilișkili olabilir.

\section{SONUÇ}

Nazilli Sağ Sahil Sulama kanalından Mart, Nisan, Mayıs ve Haziran aylarında alınan su örneklerinde $\mathrm{pH}, \mathrm{EC}$, buharlaștırma kalıntısı, erimiș madde miktarı, geçici sertlik, toplam sertlik, SAR, $\mathrm{K}^{+}, \mathrm{Ca}^{+2}, \mathrm{Na}^{+}, \mathrm{Cl}, \mathrm{CO}_{3}^{-2}, \mathrm{HCO}_{3}^{-}, \mathrm{B}$ değerlerinin aylara göre artıș gösterdiği saptanmıștır. Kanal suyunun kalite sınıfı Nisan ayında $\mathrm{C}_{2} \mathrm{~S}_{\text {I }}$ (II. Sınıf iyi su) iken, Mayıs ve Haziran aylarında artan EC değeri sonucu $C_{3} S_{1}$ sınıfına değiștiği saptanmıștır. Su kalitesi bakımından III. Sınıf 
Su (kullanılabilir) sınıfına girmesine karșın kanal suyu çilek bitkisinde yapraklarda toksik etkiler olușturmuștur ve sonuçta bitki ölümlerine yol açmıștır.

Sağ Sahil Sulama Birliği'nin kanal suyu Büyük Menderes Nehri'nden sağlandığı düșünüldüğünde bu kanaldan su alan üreticilere su kalitesi yüksek sulama suyunun sağlanması önem arz etmektedir. Bu nedenle bu nehrin geçtiği tüm yașam alanlarının ve suladığı tarım arazilerinin sağlıklı olabilmesi için, kirliliğe neden olan etmenlerin ortadan kaldırılması, kentleșme ve sanayileșme süreci içerisinde ortaya çıkan atıkların arıtılmadan nehre verilmemesi ve tarımda kontrolsüz pestisid ve kimyasal gübre kullanımının önüne geçilmesi yönünde önlemler alınması gerekmektedir.

\section{KAYNAKLAR}

Akın M, Akın G (2007) Suyun Önemi, Türkiye'de Su Potansiyeli, Su Havzaları ve Su Kirliliği. Ankara Üniversitesi Dil ve Tarih-Coğrafya Fakültesi Dergisi 47:105-118.

Akman Y, Ketencioğlu O, Kurt L, Düzenli S, Güney K, Kurt F (2004) Çevre Kirliliği (Çevre Biyolojisi). Palme Yayıncilık, Ankara.

Aktas H, Abak K, Öztürk L, Cakmak I (2006) Effect of Zinc Supply on Growth and Shoot Concentrations of Sodium and Potassium in Pepper Plants under Salinity Stress. Turkish Journal of Agriculture And Forestry $30: 407-412$.

Anonim (2018a) Devlet Meteoroloji İșleri Bölge Müdürlüğü Kayıtları, Aydın.

Anonim (2018b) Devlet Meteoroloji İșleri Bölge Müdürlüğü, www.mgm.gov.tr Erișim tarihi: 18.05.2018

Ashraf M (2004) Some Important Physiological Selection Criteria for Salt Tolerans in Plants. Flora 199:36I-376.

Aydın G, Seferoğlu S (1999) Aydın Yöresinde Kullanılan Bazı Sulama Sularının Bor Konsantrasyonlarının Bitki Beslemesi ve Toprak Kirliliği Açısından İncelenmesi. Proje No: TOGTAG-I767, Aydın.

Ayyıldız M (1990) Sulama Suyu Kalitesi ve Tuzluluk Problemleri. Ankara Üniversitesi, Ziraat Fakültesi Yayınları: I 196 Ankara.

Bañón S, Miralles J, Ochoa J, Sánchez-Blanco MJ (2012) The Effect of Salinity and High Boron on Growth,Photosynthetic Activity and Mineral Contents of Two Ornamental Shrubs. Horticultural Science (Prague) 39:188-194.

Burak S, Duranyıldız i, Yetiș Ü (1997) Ulusal Çevre Eylem Planı: Su Kaynaklarının Yönetimi. Odak Noktası Kuruluș: Devlet Su İșleri Genel Müdürlüğü.

Crohn DM, Bianchi ML (2008) Research Priorities for Coordinating Management of Food Safety and Water Quality. Journal of Environmental Quality 37:|4|I-|4|8.

D'Anna F, Incalcaterra G, Moncada A, Miceli A (2003) Effect of Different Electrical Conductivity Levels on Strawberry Grown in Soilless Culture. Acta Horticultural 609:355-360.

Daşgan HY, Koç S (2009) Evaluation of Salt Tolerance in Common Bean Genotypes by lon Regulation and Searching for Screening Parameters. Journal of Food, Agriculture Environment 7:363-372.

Delibacak S, Elmacı OL, Seçer M, Bodur, A (2002) Fertility Status, Trace Elements and Heavy Metal Pollution of
AKAROĞLU Ş N, SEFEROĞLU S Agricultural Land Irrigated from the Gediz River. International Journal of Water 2:184-195.

Ekmekçi E, Apan M, Kara T (2005) Tuzluluğun Bitki Gelișimine Etkisi. Ondokuz Mayıs Üniversitesi Ziraat Fakültesi Dergisi 20:I I8-I25.

Grieve CM, Possa JA, Grattanb SR, Suareza DL, Smithb TE (2010) The Combined Effects of Salinity and Excess Boron on Mineral İon. Relations in Broccoli. Scientia Horticulturae 125:179-187.

Jawahar P, Ringler C (2009) Water Quality and Food Safety: A Review and Discussion of Risks. Water Policy I I:680695.

Kaçan E i, Ülkü G (20I3) Gümüșçay ve Çürüksu Çayları'nın Denizli Sınırları İçinde Büyük Menderes Nehri'ne Verdiği Kirlilik Yüklerinin Saptanması. Ekoloji 22:24-34

Kacar B, Kamkat V, Öztürk Ș (2002) Bitki Fizyolojisi. Nobel Yayın Dağıtım, Ankara.

Kadayıfçı A, Tüylü Gi, Uçar Y (2004) Sulama Suyu Tuzluluğunun Soğan Bitkisinin Yumru Verimi, Bitki Su Tüketimi ve Toprak Profili Üzerine Etkileri. Tarım Bilimleri Dergisi 10:45-49.

Kepenek K, Koyuncu F (2002) Studies on The Salt Tolerance of Some Strawberry Cultivars under Glasshouse. Acta Horticulturae, 57: 297-305.

Keutgen A, Keutgen $N$ (2003) Influence of $\mathrm{NaCl}$ Salinity Stres on Fruit Quality in Strawberry. Acta Horticulturae 609:155-157.

Kurunç A, Çekiç C (2005) Response of Three Strawberry Cultivars (Fragaria $\times$ Ananassa Duch.) to Different Salinity Levels in İrigation Water. Horticultural Science (Prague) 32:50-55.

Mittler R (2002) Oxidative Stress, Antioxidants and Stress Tolerance Trends. Plants Science 7:405-4I0.

Özbay O, Ziya M, Göksu L, Alp MT, Sungur MA (20I3) Berdan Çayı (Tarsus - Mersin) Sedimentinde Ağır Metal Düzeylerinin Araștırılması. Ekoloji 22:68-74.

Öztürk S, Seferoğlu S (2010) Aydın'da Yoğun Sulu Tarım Yapılan Alanlardaki Yeraltısularının Kirlilik Durumu. I. Ulusal Toprak ve Su Kaynakları Kongresi, I-4 Haziran 2010, Eskișehir 106-II6.

Saied AS, Keutgen AJ, Noga G (2005) The Influence of $\mathrm{NaCl}$ Salinity on Growth, Yield and Fruit Quality of Strawberry Cvs. 'Elsanta' and 'Korona'. Science Horticulturae 10: 289-303.

Sekmen $A H$, Demiral T, Tosun N, Türküsay $H$, Türkan i (2005) Tuz Stresi Uygulanan Domates Bitkilerinin Bazı Fizyolojik Özellikleri ve Toplam Protein Miktarı Üzerine Bitki Aktivatörünün Etkisi. Ege Üniversitesi Ziraat Fakültesi Dergisi 42:85-95.

Süyüm K (20II) Karpuz Genetik Kaynaklarının Tuzluluk ve Kuraklığa Tolerans Seviyelerinin Belirlenmesi. Yüksek Lisans Tezi, Çukurova Üniversitesi, Adana.

Șahin Dönmez M, Ceylan M, Konuk M (20II) Dokuz Sele Çayı'na (Ulubey-Ușak) Bırakılan Sanayi Atıklarının Bazı Kültür Bitkilerinin Çimlenme ve Büyümeleri Üzerine Etkileri. Biyoloji Bilimleri Araștırma Dergisi 4:I57-I63.

Taiz L, Zeiger E (2008) Plant Physiology. The Benjamin/Cummings Publishing Company, Inc. California. 
Thorne DW, Peterson HB (1954) Irrigated Soils. Their Fertility and Management. Blakiston Comp. Inc. Toronto.

Tuncay Ö (1994). Su kalitesi. Ege Üniversitesi Ziraat Fakültesi Yayınları. No: 5 I 2.

Turhan E, Eriș A (2006) Growth and Stomatal Behaviour of Two Strawberry Cultivars under Long-Term Salinity Stress. Turkish Journal of Agricultural and Foresty 31:55-6I.

Üzal Ö, Yıldız K (20I4) Bazı Çilek (Fragaria x ananassa L.) Çeșitlerinin Tuz Stresine Tepkileri. YüzüncüYıl Üniversitesi, Tarım Bilimleri Dergisi, 24:159-167.

Yakıt S, Tuna AL (2006) Tuz Stresi Altındaki Mısır Bitkisinde (Zea Mays L.) Stres Parametreleri Üzerine $\mathrm{Ca}, \mathrm{Mg}$ ve K'nın Etkileri. Yüksek Lisans Tezi, Muğla Üniversitesi, Muğla.
Yașar F (2003) Tuz Stresi Altındaki Patlıcan Genotiplerinde Bazı Antioksidant Enzim Aktivitelerinin in vitro ve in vivo Olarak İncelenmesi. Doktora Tezi, Yüzüncü Yıl Üniversitesi, Van.

Yıldırım S, Algan M, Alkaranlı TF (2004) "Yeraltı Sulamaları”. I. Yeraltı Suları Ulusal Sempozyumu, 23-24 Aralık 2004, Konya, 3-8.

Yılmaz H (2009) Çilek. Hasat Yayınları, İstanbul.

Yurtseven E, Baran HY (2000) Sulama Suyu Tuzluluğu ve Su Miktarlarının Brokkolide (Brassica oleracea botrytis) Verim ve Mineral Madde İçeriğine Etkisi. Turkish Journal of Agricultural and Foresty. 24:185-190.

Zeng I, Poss J, Wilson C, Draz ASE, Grieve CM (2003) Evaluation of Salt Tolerance in Rice Genotypes by Physiological Characters.Euphytica, 129:281-292. 